\title{
The effect of employees' emotional intelligence and engagement on their mental health with a focus on mediating role of mental creativity
}

\section{El efecto de la inteligencia emocional y el compromiso de los empleados en su salud mental con un enfoque en la función mediadora de la creatividad mental}

\author{
FAYEGH-MORADIHA, Hadi $\uparrow$, SHIRAZIAN, Zahra*, SALIMI, Freidoon and FAYEGH-MORADIHA, \\ Mehdi
}

Department of Management, Malayer Branch, Islamic Azad University, Malayer, Iran.

ID $1^{\text {st }}$ Author: Hadi, Fayegh-Moradiha / ORC ID: 0000-0001-6036-9836

ID $1^{\text {st }}$ Coauthor: Zahra, Shirazian / ORC ID: 0000-0003-2457-9216

ID $2^{\text {nd }}$ Coauthor Freidoon, Salimi / ORC ID: 0000-0003-4507-4313

ID $3^{\text {rd }}$ Coauthor: Mehdi, Fayegh-Moradiha / ORC ID: 0000-0002-6397-7228

DOI: $10.35429 / E J M .2020 .24 .11 .1 .11$

Received: January 19, 2020; Accepted: June 1, 2020

\begin{abstract}
The present study aimed to investigate the effect of employees' emotional intelligence and engagement on their mental health with a focus on the mediating role of mental creativity. This descriptive survey was a quantitative and applied study using cross-sectional method. Statistical population of the study encompassed 57000 employees of Tehran Municipality Organization, from whom 381 persons were selected. The study data was collected by a questionnaire whose validity and reliability were confirmed. In order to analyze the data, structural equation modeling and Smart PLS software were adopted. The findings of the present study confirmed the significant effect of emotional intelligence on mental health among the employees of Tehran Municipality Organization. Moreover, the results revealed the positive and significant effects of the engagement on mental health, emotional intelligence on mental creativity, engagement on mental creativity, and mental creativity on mental health among the employees of Tehran Municipality Organization. Finally, the hypotheses of the study were confirmed.
\end{abstract}

Emotional intelligence, Mental health, Mental creativity, Engagement

\begin{abstract}
Resumen
El presente estudio tuvo como objetivo investigar el efecto de la inteligencia emocional y el compromiso de los empleados en su salud mental con un enfoque en el papel mediador de la creatividad mental. Esta encuesta descriptiva fue un estudio cuantitativo y aplicado que utilizó un método transversal. La población estadística del estudio abarcó a 57000 empleados de la Organización del Municipio de Teherán, de los cuales se seleccionaron 381 personas. Los datos del estudio fueron recolectados por un cuestionario cuya validez y confiabilidad fueron confirmadas. Para analizar los datos, se adoptó el modelado de ecuaciones estructurales y el software Smart PLS. Los hallazgos del presente estudio confirmaron el efecto significativo de la inteligencia emocional en la salud mental entre los empleados de la Organización Municipal de Teherán. Además, los resultados revelaron los efectos positivos y significativos del compromiso sobre la salud mental, la inteligencia emocional sobre la creatividad mental, el compromiso sobre la creatividad mental y la creatividad mental sobre la salud mental entre los empleados de la Organización Municipal de Teherán. Finalmente, se confirmaron las hipótesis del estudio.
\end{abstract}

Inteligencia emocional, Salud mental, Creatividad mental, Compromiso

Citación: FAYEGH-MORADIHA, Hadi, SHIRAZIAN, Zahra, SALIMI, Freidoon and FAYEGH-MORADIHA, Mehdi. The effect of employees' emotional intelligence and engagement on their mental health with a focus on mediating role of mental creativity. ECORFAN Journal-Mexico. 2020. 11-24: 1-11.

\footnotetext{
* Correspondence author: (SHIRAZIAN, Zahra)

$\dagger$ Researcher contributing first author.
} 


\section{Introduction}

Emotional intelligence appears to be a developed form attention to human beings in organizations, and is a new and desirable tool provided to the business managers and market theorists to lead individuals and customers inside and outside their organizations in order to meet their satisfaction. Awareness of individuals' emotional intelligence in an organization can help the organizational managers to solve many problems since when they accept that humans differ in terms of emotional intelligence, they will have the same behavioral expectations from all employees (Goleman, 2004). Work engagement is a psychological state in which a person devotes himself to his or her role in an organization. Furthermore, work engagement is considered to do one's best in performing the work roles. It, as a positive construct, has a high potential in explaining the desired organizational outcomes. William Kane, as the first researcher of the field, defines work engagement as truly bending over backwards for performing their work roles (Saks, 2006). Since the employees' mental health has a great influence on their creativity, the issue has been of a particular interest to many communities and organizations. Most people spend a lot of time at workplace; hence, the workplace consists a major part of each individual's life, which can significantly affect his health and his community'. Mental health refers to how individuals evaluate their life.

Such an evaluation may be cognitive. The informed assessment of the overall satisfaction with life leads to experiencing pleasant or unpleasant feelings in response to life (Ghadami, 2017). Organizational creativity is an iterative process of finding solutions to the problems, which brings significant changes to the organization in the pursuit of success. Organizational effectiveness is one of the most significant features of leading organizations, which has a significant relationship with intraorganizational components, including efficiency, creativity and talent. One of the basic issues in organizational theory is organizational efficiency as it is regarded as a benchmark in evaluating organizational performance (Lewis et al., 2009).
In this regard, the present study was to determine the effect of the employees' emotional intelligence and engagement on their mental health with a focus on the mediating role of creativity. In this article, the statement of the problem and theoretical foundations are first addressed and then the empirical background is reviewed. Afterwards, the methodology is covered and the collected data are analyzed. The study is concluded with the findings.

\section{Significant of the Study}

Several factors affect individuals' effectiveness in an organization. Emotional intelligence is one of the factors that greatly influence each person's behavior. Emotional intelligence is a kind of emotional information processing that involves an appropriate assessment of emotions in oneself and others, the proper expression of emotions and the adaptive generalizability of emotions (Mayer \& Salovey, 2000). Emotional intelligence encompasses a set of non-cognitive abilities and skills increasing an individual's ability to succeed in coping with pressures and environmental constraints. In this regard, emotional intelligence is a variable that seems to be related to individuals and clients' tensions (Rogers et al., 2006). Each organization certainly seeks for finding solutions and creating space in order to create an organizational sense of belonging among its staff in order not only to convey a positive attitude towards the organization and to promote job satisfaction but also to prevent employees from being demotivated and burned out. Thus these committed employees who are the most valuable assets and capital to the organization are to take steps towards excellence and achieve their business and commercial goals. In the case of role engagement, the employees use or express all their physical, cognitive, and emotional aspects (Agyemang \& Ofeil, 2013). Mental health is one of the variables that are now of great importance in the workplace, implying that how people evaluate their lives. Individuals' mental health is one of the variables influenced by their job control. In this regard, the managers of successful organizations know that the achievement of organizational goals depends on their employees' mental health as such one of the features of a healthy organization is that the physical and mental health of its employees is as much of importance to its manager as the organizational production and productivity are focused (Paul et al., 2014). 
Today's complex life is constantly evolving, and creativity and innovation are a necessity for the continuation of active life. Organizations are increasingly eager to become more creative, invest on their creativity, and understand and develop the conditions leading to creativity within their work environment. Creativity can be a powerful source of work competition. To enhance creativity in the organization and to nurture creative features among the employees, specific circumstances and contexts are required. One of the most important ways to nurture creativity is to construct a creative and flexible structure in an organization (Lewis et al., 2009). The significance of the present study can be explained with regard to the high workload of the Tehran Municipality's staff and their increasing work concerns. Since they spend most of their time in their workplace, the present study was to investigate the effect of employees' emotional intelligence and engagement on their mental health with a focus on the mediating role of mental creativity. We intend to measure the level of employees' affiliation and their mental health. The study further was to assess the employees' engagement and mental health and to examine the impact of emotional intelligence and work engagement on the latter variable.

\section{Theoretical Background of the Research}

\section{Emotional intelligence}

Emotional intelligence is a concept aiming at explaining and changing the status of human emotions, feelings, and abilities. IQ fails to wellexplain the different destinies of individuals with the same educational opportunities and conditions. Ideally, IQ can only explain $20 \%$ of life success and the other $80 \%$ depends on other factors, and individuals' destiny in many cases depend on skills forming emotional intelligence or EQ (Behbahani, 2014). One of the advantages of emotional intelligence in comparison to IQ is that it is acquired and can be easily learned, developed, improved, and modified. Neither can education nor experience, information, and intelligence determine why a person is successful and another one is not. According to Mayer and Salovey (1997), emotional intelligence is an ability to understand and comprehend emotions to evaluate the thoughts and moods and to adjust them in such a way as to bring about rational-emotional excellence (Golman, 2004).

\section{Work engagement}

Work engagement is characterized by concepts such as positive, satisfactory, and work-related mental states through vitality, sacrifice, and fascination indicators. Vitality refers to high energy level and mental resilience at work; sacrifice represents a person's intense engagement with work and experience, sense of meaningfulness, passion, and challenge; and fascination refers to an individual's full concentration and joyful enthusiasm in the work through which the time is spent quickly and one cannot get rid of work easily (Lockwood, 2007). With nurturing work engagement among the employees, positive synergies would be enhanced among the individuals and organizations, leading to positive outcomes for both groups. These outcomes can include positive attitudes, strong sense of belonging (job satisfaction and organizational commitment), mental health such as enhanced positive emotions and decreased burnout, work-related and non- work-related performance, increased intrinsic motivation, individual initiative, leading behaviors, and the acquisition of personal and business resources (Parker et al., 2010).

\section{Mental health}

Since the creation of mankind, human beings have always been concerned with their health; however, its physical aspect is generally considered, and less attention is paid to its psychological dimension. According to the World Health Organization, "Unhealthiness does not exclusively refer to a deficiency or sickness; however, it indicated a full status of physical wellbeing" (Biggs et al., 2010). Kinsberg introduces the mental health as a mastery and skill in proper communication with the environment, especially with three important life spaces, including love, work, and recreation. In his opinion, acquiring the ability to continue work in the future, having a pleasant family environment, avoiding issue which are in conflict the law, enjoying life, and using the right opportunities are benchmarks for mental balance and health (Astbari, 2008). The World Health Organization describes mental health as follows: "Mental health is integrated with the umbrella concept of health, and mental health and indicates the full ability to play social, mental, and physical roles. Unhealthiness is not just a disease along with deficiency (Biggs et al., 2010). 


\section{Mental Creativity}

For a long period of time, theorists assumed that creativity was an inherited and intrinsic process; thus, it seemed that the world was supposed to nurture a limited number of creative artists, scholars, and talented individuals, and it was not responsible for other people who were not talented. (Straicher et al., 2012). If we consider creativity to be intrinsic, we in many aspects will be in a full agreement with the beliefs of those who perceive intelligence or identity formation as intrinsic. While the basic principle of psychology now allows us to believe that the creativity process is not intrinsic and can be learned. In this process, creativity is not a preplanned but a variable process (Alavi et al., 2003). There are proposed several definitions for creativity in the literature. In Persian dictionaries, creativity means creation and the ability to combine ideas or creations (Vidergor, 2013).

\section{Empirical Background of the Study}

- Ghadami (2017) conducted a study on the relationship between mental health and quality of life culture among married women in Sari. The statistical population of the study consisted of all married women in District II, Sari, Iran, of whom 100 married women were randomly selected as a statistical sample. The results of the study showed a positive and significant relationship between mental health and the quality of life culture among married women in Sari.

- Haghighi and Korbkandi (2017) examined the impact of transformational leadership on employee's engagement. The study was applied in terms of objective and a descriptive survey in terms of data collection. The statistical population included all employees of the National Organization for Civil Registration in Tehran $(\mathrm{N}=300)$, of whom 120 persons participated in the study. The results indicated a positive and significant relationship between transformational leadership and employees' engagement.
- Tabarsa and Korbkandi (2017) examined relationship between employee's work engagement and performance. The statistical population of this research is the All staff of the Deputy Directorate for Development and Resources at the Ministry of Economic Affairs and Finance $(\mathrm{N}=200)$ formed the study population. The sample size was 80 and the Pearson coefficient for the correlation between employee's engagement and performance was estimated to be 0.438 , indicating that there was a positive and significant relationship between these two variables.

- Liqun Wen et al. (2017) studied the influence of leader's creativity on employees' and team creativity with regard to the mediating role of identification with leader. The statistical population of the study encompassed 35 organizations in the UK. They found that leader's creativity had a positive and significant effect on employees' and team creativity. Furthermore, the mediating role of identification with leader influenced employees' and team creativity.

- Nan Hu et al. (2017) investigated the role of conflict and creativity in inter-organizational teams with regard to the moderating role of shared leadership. The statistical population of their study consisted of private companies in China, which were operating in the software industry. The results of their research showed a significant and negative relationship between conflict and creativity in the interorganizational teams. Moreover, the results suggested that when shared leadership gets stronger, the negative relationship between conflict and creativity decreases.

- Mike et al. (2015) considered the relationship between emotional intelligence and mood. In this research, the emotional intelligence components included self- awareness, selfmanagement, social awareness, and relationship management. They concluded that that these two variables (emotional intelligence and mood) have a significant relationship with each other. 


\section{Conceptual Model of the Study}

In the present study, Abdullah and Mushtaq's (2018) Emotional Intelligence Model, Schaufeli and Bakker's (2013) work engagement scale, Gorczynski's et al. (2017) mental health, and Huang and Shiau's (2018) measure for employees' mental creativity were used. Accordingly, the researcher developed the study conceptual model of as follows and proposed the following hypotheses:

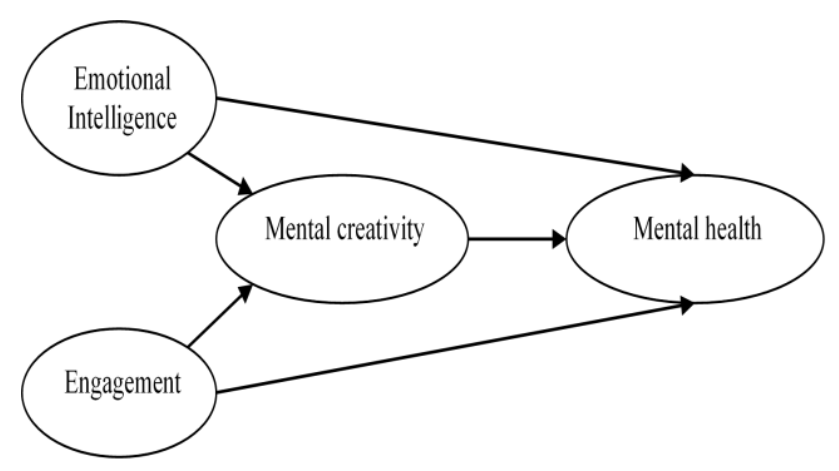

Figure 1 Research conceptual model

\section{Research Hypotheses}

- Tehran Municipality employee's emotional intelligence has a positive and significant effect on their mental health.

- Tehran Municipality employee's engagement has a positive and significant effect on their mental health.

- Tehran Municipality employee's emotional intelligence has a positive and significant effect on their mental creativity.

- Tehran Municipality employee's engagement has a positive and significant effect their mental creativity.

- Tehran Municipality employee's mental creativity has a significant and significant effect on their mental health.

\section{Research Methodology}

The present study was considered to be applied in terms of research objectives. From the standpoint of the data type, it should be said that, due to the use of the questionnaire and the conversion of qualitative values into quantitative ones, this research was a quantitative study with a positivist approach.
Further, regarding its procedure, since the study was carried out at a point of time, it was cross-sectional. The statistical population of the study consisted of all Tehran Municipality employee ( $\mathrm{N}=57000)$. According to Morgan's Table, 381 persons were selected as the sample size using stratified sampling method.

It should be noted that the reason for the low sample size and the number (381 individuals) is that the researcher used a Morgan table to estimate the sample size and the sample size was estimated based on this table, which is a global standard table, for the research population (57000 individuals). Therefore, 381 questionnaires were distributed to the respondents and the same number was collected and categorized.

\section{Research Instruments}

A questionnaire was used to collect data required in the present study. In this study, four questionnaires were used as follows:

- Emotional Intelligence Questionnaire: To measure the employees' emotional intelligence, a standard questionnaire consisting of eight questions and four components (self-awareness, selfmanagement, social awareness, and relation management) was used.

- Employees' Engagement Scale: A standard questionnaire consisting of nine items and three components (namely vitality, sacrifice, and fascination) was used to assess the employees' engagement.

- Mental Health Questionnaire: To assess the employees' mental health, a standard questionnaire consisting of seven items and two components (namely awareness of information, and self-care knowledge) was used.

- Mental Creativity Questionnaire: To measure mental creativity, a standard questionnaire consisting of nine questions and three components (namely expertise, creative thinking, and motivation) was used. 
Confirmatory factor analysis and goodness of fit indices were used to determine the research questionnaire's validity and Cronbach's alpha was used to measure reliability. The result of factor analysis and Cronbach's alpha coefficients are presented in Table 1.

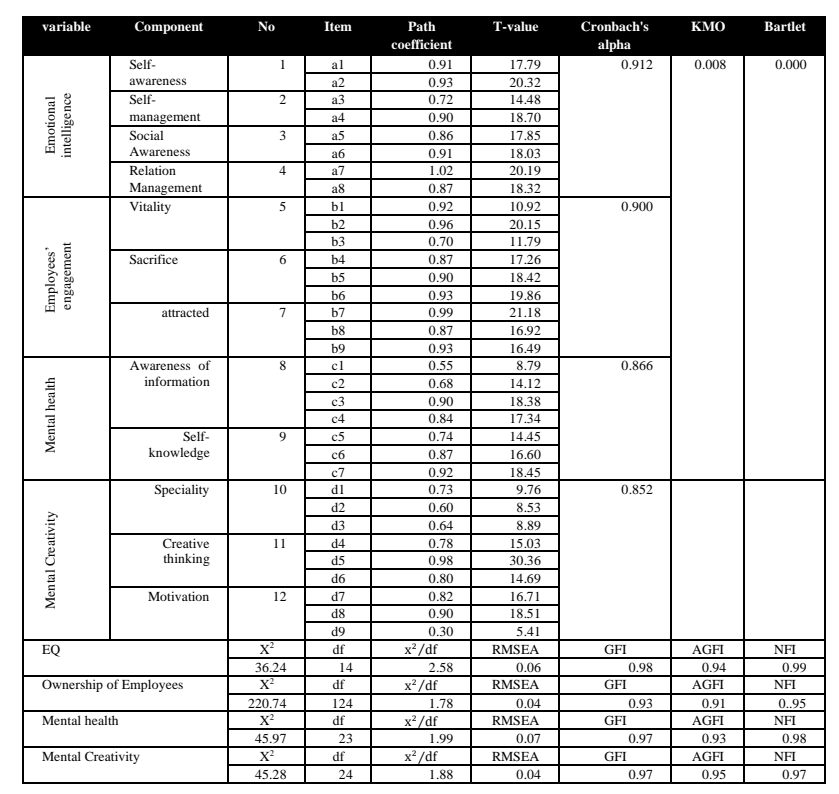

Table 1 Validity and Reliability of research questionnaire

According to Table 1, the Cronbach's alpha coefficients for all components were greater than the recommended value of 0.7 , indicating that the reliability of the research questionnaires was acceptable. The KMO index values for each of the four questionnaires were above the minimum level of 0.6 and the significance level of Bartlet's statistics was $<0.05$; therefore, the research sample was sufficient to perform the confirmatory factor analysis. The values of the confirmatory factor analysis for the standard coefficients of each questionnaire were at a suitable level. The Tvalues of the confirmatory factor analysis for the four questionnaires ranged from +1.96 to -1.96 , and revealed an acceptable level. Also, the face and content validity of the questionnaire confirmed its validity. Thus, the validity of the research instrument was accepted. In other words, the research tools can be considered as valid and reliable. Also, the results of goodness of fit indices in the confirmatory factor analysis indicated that all of the four questionnaires were well-fitted.

\section{Research Findings}

Demographic Findings
The respondents' outline such as their gender, age, education, service record is examined in Table 2 as it follows:

\begin{tabular}{|c|c|c|c|}
\hline Variables & Index & Number & Frequency \\
\hline \multirow[t]{2}{*}{ gender } & males & 305 & $80 / 1$ \\
\hline & females & 76 & $19 / 9$ \\
\hline \multirow[t]{4}{*}{ age } & $\begin{array}{l}\text { under } 30 \text { years } \\
\text { old }\end{array}$ & 20 & $5 / 2$ \\
\hline & between $30-40$ & 85 & $22 / 3$ \\
\hline & between $40-50$ & 180 & $47 / 2$ \\
\hline & $\begin{array}{l}\text { over } 50 \text { years } \\
\text { old }\end{array}$ & 96 & $25 / 2$ \\
\hline \multirow[t]{4}{*}{ education } & diploma & 18 & $4 / 7$ \\
\hline & $\begin{array}{l}\text { bachelor's } \\
\text { degree }\end{array}$ & 38 & 10 \\
\hline & $\begin{array}{l}\text { undergraduate } \\
\text { education }\end{array}$ & 160 & 42 \\
\hline & $\begin{array}{l}\text { postgraduate } \\
\text { and higher } \\
\text { degrees }\end{array}$ & 165 & $43 / 3$ \\
\hline \multirow[t]{4}{*}{$\begin{array}{l}\text { Service } \\
\text { record }\end{array}$} & $\begin{array}{l}\text { less than } 5 \\
\text { years }\end{array}$ & 28 & $7 / 3$ \\
\hline & between $5-10$ & 89 & $23 / 4$ \\
\hline & between $10-15$ & 120 & $31 / 5$ \\
\hline & $\begin{array}{l}\text { more than } 15 \\
\text { years }\end{array}$ & 144 & $37 / 8$ \\
\hline
\end{tabular}

Table 2 Demographic Findings

According to the demographic analysis of the respondents on gender, about $80.1 \%$ (305) of the respondents were males and the rest were females, $19.9 \%$ (76). Regarding their age, about $5.2 \%$ (20) of respondents were under 30 years old, and $22.3 \% \quad(85)$ and $47.2 \%$ (180) were, respectively, between $30-40$ and 40-50, and $25.2 \%$ (96) of them were over 50 years old. With respect to the education, $4.7 \%$ (18) had a diploma, $10.1 \%$ (38) had a bachelor's degree, $42.0 \%$ (160) had undergraduate education, and $43.3 \%$ (165) had postgraduate and higher degrees. Regarding the service record, about $7.3 \%$ (28) of the respondents had a service record less than 5 years, $23.4 \%$ (89) and $31.5 \%$ (120) with a service record, respectively, between 5-10 and 10-15 years, and $37.8 \%$ (144) had a service record of more than 15 years.

Before analyzing the data, their distribution was evaluated using the Kolmogorov-Smirnov test, and it was revealed that the distribution of the variables was not normal. Hence partial least squares method, which can be run in the Smart PLS software, was adopted. Therefore, the covariance-based (SEM) technique based on LISER software cannot be used since it is sensitive to data normality. This technique can be used when the data follow the normality rule.

FAYEGH-MORADIHA, Hadi, SHIRAZIAN, Zahra, SALIMI Freidoon and FAYEGH-MORADIHA, Mehdi. The effect of employees' emotional intelligence and engagement on their mental health with a focus on mediating role of mental creativity. ECORFAN Journal-Mexico. 2020 
Thus, the data presented in this research are abnormal, those tests and techniques that are not sensitive to the normality or abnormality of the data should be used.

In other words, the main reason for using Smart PLS software is that the data does not follow a normal distribution. Other factors that can be mentioned include constructive measurement models; good predictive power; model complexity (large number of structures and indices); theory development; convergence study; testing theory and hypothesis; and testing hypotheses involving moderating variables. Therefore, the best technique for data analysis is to use the partial least squares approach that is applied in this research. The visual output, estimation of hypotheses, path coefficients, and significant coefficients are shown in the following figures.

\section{Structural Path Coefficients of Research Hypotheses}

\section{The Document related to using the scales}

The Partial Least Squares technique is a nonparametric method that is a good substitute for the structural equation model. The partial least squares method is less sensitive to sample size and data normality is not necessary. While, massive data volumes are needed to perform the structural equation technique and the LISREL software.

Similar to the structural equation model in the figure, two concepts of the latent variable and the observed variable must also be shown. These variables can be independent or dependent. The observed variables are the items or questions that are displayed in the rectangles in the following figure:

The least squares model is partitioned into two outer and inner models: the outer model indicates the relationship between items (questionnaire questions) and factors (latent factors) and it is equivalent to confirmatory factor analysis or measurement model in LISREL and AMOS software. The inner model is similar to the path analysis and structural part of a structural equation model. After testing the outer model, it is necessary to develop an inner model that indicates the relationship between the latent variables.
The research hypotheses can be examined by using the inner model. Standard estimation is used to identify the strength and direction of the relationship between the components. These values should be above 0.3 , which are also indicated in the following figure:

Whatever the factor loading is higher, the greater is the strength of the relationships. The tstatistic should be estimated for examining the significance. For this purpose, bootstrapping or jackknife cutting is used. If the t-statistic is above 1.96, the relationship is significant. Unlike the structural equation model, there are not many indicators for fitting in the partial least squares. Three indices are commonly used to fit the inner model, including $\mathrm{R} 2$ coefficient of determination, GOF, Q2 Blindfolding. Therefore, these indices are used to determine whether the model has a desirable fitting. Then, the aforementioned issues have been discussed in the following figures.

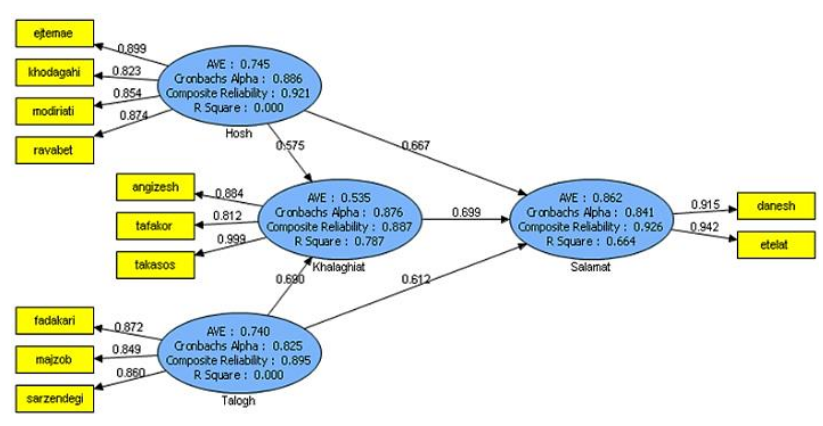

Figure 2 Structural path coefficients of research hypotheses

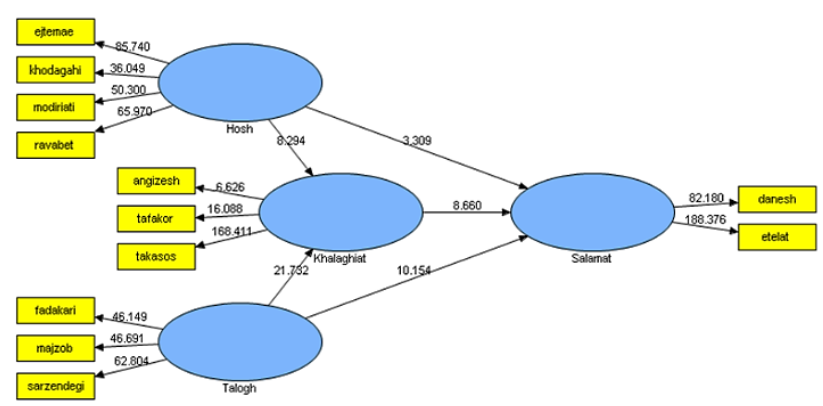

Figure 3 Estimation of P-values for research hypotheses

Since the study models for the main hypothesis were set at the confidence level of 0.92 and at the error level of 0.01 , the minimum acceptable value for the T-statistics is 1.96. As the above figure shows, the path coefficients of the research hypotheses were significant. Table 3 presents the path coefficients along with the Pvalues, and direct and indirect effects. 


\begin{tabular}{|c|c|c|c|c|c|c|c|}
\hline $\begin{array}{c}\text { Research } \\
\text { hypotheses }\end{array}$ & $\begin{array}{l}\text { pathe } \\
\text { From }\end{array}$ & To & $\begin{array}{l}\text { direct } \\
\text { effect }\end{array}$ & $\begin{array}{l}\text { indirec } \\
\text { effect }\end{array}$ & $\begin{array}{l}\text { Total } \\
\text { effect }\end{array}$ & t-value & Result \\
\hline First & EQ & $\begin{array}{l}\text { Mental } \\
\text { health }\end{array}$ & 0.667 & --- & 0.667 & 3.309 & Confirmed \\
\hline Second & Engagement & $\begin{array}{l}\text { Mental } \\
\text { health }\end{array}$ & 0.612 & --- & 0.612 & 10.154 & Confirmed \\
\hline Third & EQ & $\begin{array}{l}\text { Mental } \\
\text { Creativity }\end{array}$ & 0.575 & -- & 0.575 & 8.294 & Confirmed \\
\hline Fourth & Engagement & $\begin{array}{l}\text { Mental } \\
\text { Creativity }\end{array}$ & 0.690 & -- & 0.690 & 21.732 & Confirmed \\
\hline Fifth & $\begin{array}{l}\text { Mental } \\
\text { Creativity }\end{array}$ & $\begin{array}{l}\text { Mental } \\
\text { health }\end{array}$ & 0.699 & -- & 0.699 & 8.660 & Confirmed \\
\hline
\end{tabular}

Table 3 P-values and path coefficients for the structural path model of research hypotheses

The above table showed that the emotional intelligence directly affected mental health (0. 677), engagement with a value of 0.612 directly affected mental health, emotional Intelligence with a value of 0.575 had a direct impact on mental creativity, engagement with a value of 0.690 directly affected mental creativity, and mental creativity with a value 0.699 directly influenced mental health. All paths were statistically significant at 0.99 and the error level of 0.01 .

After assessing the research hypotheses, the quality indices or fit indices of the model hypotheses should be assessed. In structural path modeling, there are three categories of indices for this purpose: outer model indices, inner model indices, and total model indices. In the table below, these three indices are shown.

\begin{tabular}{|c|c|c|c|c|c|c|c|c|}
\hline \multirow[t]{2}{*}{ Variables } & \multicolumn{3}{|c|}{ outer model indices } & \multicolumn{2}{|c|}{ inner model } & \multicolumn{3}{|c|}{ Model quality indices } \\
\hline & $\boldsymbol{a}$ & p & AVE & $r^{2}$ & $\mathbf{Q}^{2}$ & Com & Red & GOF \\
\hline $\begin{array}{l}\text { Emotional } \\
\text { intelligence }\end{array}$ & 0.886 & 0.921 & 0.745 & --- & 0.627 & 0.745 & --- & 0.734 \\
\hline $\begin{array}{l}\begin{array}{l}\text { Employee } \\
\text { engagement }\end{array}\end{array}$ & 0.825 & 0.895 & 0.740 & --- & 0.619 & 0.740 & -- & \\
\hline $\begin{array}{l}\text { Mental } \\
\text { health }\end{array}$ & 0.841 & 0.926 & 0.862 & 0.664 & 0.710 & 0.862 & 0.551 & \\
\hline $\begin{array}{l}\text { Mental } \\
\text { Creativity }\end{array}$ & 0.876 & 0.887 & 0.535 & 0.787 & 0.546 & 0.619 & 0.261 & \\
\hline
\end{tabular}

Table 4 Evaluation of inner, outer, and total model indices of research hypotheses

Since the Cronbach's alpha coefficients and the composite reliability was $>0.7$, the model blocks had an acceptable reliability. Also, the AVE index value was also greater than the minimum value of 0.5 ; thus, the outer model indices were in an acceptable status. The evaluation indices of the inner model also revealed that the model was in an acceptable status since the coefficients of determination were at a high level and the Stone-Geisser Criterion $\left(\mathrm{Q}^{2}\right)$ was not zero. The total model indices were also in an appropriate status, and the GOF index confirmed that the model could predict the research hypotheses up to 0.73 .

\section{Discussion and Conclusion}

The present study aimed to examine investigate the effect of Tehran Municipality employees' emotional intelligence and engagement on their mental health with a focus on the mediating role of mental creativity. Based on the test results for the first hypothesis, it was determined that employees' emotional intelligence had a direct effect on their mental health (0.667). The findings was in line with the findings of Tabarsa and Korbkandi (2017), Balouch (2016), Tavangar (2015), Mortazavi and Monirian (2015), Heidari (2015); Lekwan et al. (2017), Nan $\mathrm{Hu}$ et al. (2017); Mike et al. (2015), and Woroujim and Derval (2010). The results of the second hypothesis testing showed that the Tehran Municipality employees' engagement (0.612) had a direct effect on their mental health. The findings were in a similar vein with the findings of some other researchers, including Ghadami (2017); Haghighi and Korbkandi (2017); Tabarsa and Korbkandi (2017); Heidari (2015); Lekwan et al. (2017), Nan $\mathrm{Hu}$ et al. (2017), and Mike et al. (2015). The third hypothesis also confirmed the direct effect of Tehran Municipality employees' emotional intelligence on their mental creativity (0.575). This finding confirmed the findings of Ghadami (2017), Tavangar (2015), Mortazavi and Monirian (2015), Heidari (2015); Mike et al. (2015), Behbahani (2014); Fabin (2012), and Ahmad et al. (2012). The results obtained from the analysis of the fourth hypothesis indicated that the Tehran Municipality employees' engagement (0.690) had a significant effect on their mental creativity. The results of this research hypothesis were in agreement with the findings of Haghighi and Korbkandi (2017), Tabarsa and Korbkandi (2017), Balouchi (2016), Behbahani (2014), Fabin (2012), and Ahmad et al. (2012). Finally, the test results for the fifth hypothesis showed that Tehran Municipality employees' mental creativity had a positive effect on their mental health (0.699). This finding confirmed the findings of Tabarsa and Korbkandi (2017), Balouchi (2016), Tavangar (2015), Mortazavi and Monirian (2015), Heidari (2015), Lekwan et al. (2017), and Woroujim and Derval (2010).

Based on the results of analyzing the research hypothesis, it can be inferred that the mental health of the employees in the organization will be enhanced by increasing their emotional intelligence, and hence, it will improve the performance and empowerment of employees in the organization. 
Moreover, emotional intelligence enhances employees' mental creativity and enables them to take steps in solving their organizational and occupational problems by taking initiative and using their minds to solve the problem. It is worth noting that as the mental creativity and health in the employees increase, the managers of the organization will also have a sense of confidence and belonging that their subordinates have achieved to the extent that they have stepped in line with the vision and mission of the organization, and it gives the organization a competitive advantage over other organizations.

Based on the findings of these hypotheses, it is recommended that emotional intelligence tests be used to recruit individuals in this organization (Tehran municipality) so that the most competent selected ones will be the most intelligent persons in organizational positions. The organization managers should take steps towards nurturing the employees' engagements through creating an appropriate and suitable space for their employees. They should also enhance their employees' energy level and mental health and increase their feelings of meaningfulness and desire to work. When recruiting the employees, the managers are also suggested to pay particular attention to their individual attributes. Regarding the order of their significance, these attributes respectively are individual intelligence, emotional intelligence, personality, creativity, and motivation since individuals with higher mental creativity and intelligence level can better have an accurate interpretation of the information. The following measure are also recommended to be adopted in organizations: encouraging creative efforts by employees, using new ideas for reforming work processes, setting up regular meetings to solve problems and learning from experiences, developing proposal systems in the organization, and increasing the possibility of interacting with others. These in turn would promote the employees' work engagement in the organization.

\section{Suggestions for Future Research}

Conducting a research opens a door for the future researches and the need for more studies becomes observable. The following subjects are recommended for other researchers. According to the results of the present study, future researchers are suggested to:
- Compare and analyze the variables of emotional intelligence and mental creativity with other variables such as innovation and organizational intelligence.

- Measure the employees belonging variable along with other components such as organizational commitment and quality of working life and compare its results with the those presented in this study.

- Investigate the effects of improving employees' mental health on job motivation and competency principles in other organizations and compare its results with the those presented in this study.

- Conduct a research on the relationship between mental creativity and emotional intelligence in other organizations as well as other stateowned and private companies and analyze and compare the results.

- Consider the emotional intelligence variable along with other organizational variables such as self-esteem and social responsibility.

\section{Research Limitation}

There are limitations to any research project that are beyond the researcher control and have other reasons, including environmental factors. Generally, these limitations inevitably affect the research process. Introducing and describing the factors that indicate the scope and limitations of a research are among the merits of a scientific work and are usually considered by reviewers (Mansurian, 2010). There are also some limitations to this research, as it follows:

- Gaining the trust of the sample population to fill the questionnaire was one of the problems encountered in this study.

- Situational differences, such as the time of filling the questionnaire, the mental condition of the respondents, and other variables, make it difficult to generalize the findings.

Data gathering based on the questionnaire is another limitation to the research. Since the questionnaire measures individuals' perception of reality, one should not overlook the possibility that this perception be not fully consistent with the reality. 


\section{References}

Abdullah Alam, Mushtaq Ahmad, (2018). "The role of teachers' emotional intelligence in enhancing student achievement", Journal of Asia Business Studies, https://doi.org/10.1108/JABS-08-2015-0134.

Agyemang. C.B., Ofeil. B. S. (2013). Employee work engagement and organizational commitment: a comparative study of private and republic sector organization in Ghana. European Journal of Business and Innovation Research, Vol.1, No.4: 20-33,

Alavi, S. H. R., Khezri, M., \& Ghezel Eiagh, M. (2003). On the relationship between employees' creativity and organizational atmosphere, Journal of Management Message, No.7 \& 8, pp. 133-160.

Behbahani, A. A. (2014), a comparative Study of the Relation between Emotional Intelligence and Employee's Performance. Procedia - Social and Behavioral Sciences 30, pp 386 -389.

Biggs, D., Hovey, N., Tyson, P.J. and MacDonald, S. (2010), Employer and employment agency attitudes towards employing individuals with mental health needs, Journal of Mental Health, Vol. 19, pp. 505-16.

Cai, W., Khapova, S., Bossink, B., Lysova, E., \& Yuan, J. (2020). Optimizing employee creativity in the digital era: Uncovering the interactional effects of abilities, motivations, and opportunities. International Journal of Environmental Research and Public Health, 17(3), 1038.

Christensen-Salem, A., Walumbwa, F. O., Hsu, C. I. C., Misati, E., Babalola, M. T., \& Kim, K. (2020). Unmasking the creative self-efficacycreative performance relationship: the roles of thriving at work, perceived work significance, and task interdependence. The International Journal of Human Resource Management, 1-27.
Del Carmen Pérez-Fuentes, M., Linares, J. J. G., Jurado, M. D. M. M., Márquez, M. D. M. S., \& Martínez, Á. M. (2020). The mediating role of cognitive and affective empathy in the relationship of mindfulness with engagement in nursing. BMC Public Health, 20(1), 1-10.

Ghadami, M. (2017). An investigation of the relationship between mental health and the quality of life culture among married women in Sari. First International Conference on Culture, Psychopathology and Education.

Golman, Daniel, (2004). Emotional Intelligence. Translated by Nasrin Parsa, Roshd pub. (3rd Ed.).

Gong, Y., Wu, Y., Huang, P., Yan, X., \& Luo, Z. (2020). Psychological Empowerment and Work Engagement as Mediating Roles Between Trait Emotional Intelligence and Job Satisfaction. Frontiers in Psychology, 11.

Giao, H. N. K., Vuong, B. N., Huan, D. D., Tushar, H., \& Quan, T. N. (2020). The Effect of Emotional Intelligence on Turnover Intention and the Moderating Role of Perceived Organizational Support: Evidence from the Banking Industry of Vietnam. Sustainability, 12(5),

1857

Haghighi, M. A. \& Korbkandi, M. (2017). The impact of transformational leadership on employee's engagement. Annual Conference of New Paradigms of Management in the Field of Intelligence.

Lewis; Herdert F. lock and sexton (2009). Organizational capability, efficiency, and effectiveness in major league Baseball: 19012002, European Journal of operational Research 731-740

Li-Chun Huang, Wen-Lung Shiau, (2018). "Factors affecting creativity in information system development: Insights from a decomposition and PLS-MGA", Industrial Management \& Data Systems, Vol. 117 Issue: 3, pp.496-520, https://doi.org/10.1108/IMDS-082015-0335. 
Liqun Wen, Mingjian Zhou, Qiang Lu , (2017). The influence of leader's creativity on employees' and team creativity: Role of identification with leader, Nankai Business Review International, Vol. 8 Iss: 1, pp.22 - 38.

Lockwood, N. R. (2007). "Leveraging employee engagement for competitive advantage: HR's strategic role". HR Magazine. Vol. 52, No. 3, pp. 1-111.

Marin-Garcia, J.A., \& Alfalla-Luque, R. (2019). Key issues on Partial Least Squares (PLS) in operations management research: A guide to submissions. Journal of Industrial Engineering and Management, 12(2), 219. 240.https://doi.org/10.3926/jiem.2944.

Mayer, Y.D salovey PQ and Caruso, D. (2000). Models of emotional intelligence In R.Y Sternberg (ed) Hand book of intelligence (pp.396-420)new York.

Mike Eniola and Busari A.O(2015).Emotional Intelligence in Promoting Self-Efficacy of the visually Impaired Fresh students of Federal College of Education. Nigeria Journal of Medwell. Vol 2.page:152-155.

Nan $\mathrm{Hu}$, Zhi Chen , Jibao Gu, Shenglan Huang , Hefu Liu. (2017). Conflict and creativity in inter-organizational teams: The moderating role of shared leadership, International Journal of Conflict Management, Vol. 28 Iss: 1, pp.74 -102 .

Parker, S. L., Jimmieson, N. L. \& Amiot, C. E. (2010). Self-determination as a moderator of demands and control: Implications for employee strain and engagement. Journal of Vocational Behavior. 76, 52-67.

Paul, Gorczynski. Wendy, Sims, Schouten. Denise, Hill. Janet, Clare Wilson, (2017), " Examining mental health literacy, help seeking behaviours, and mental health outcomes in UK university students", The Journal of Mental Health Training, Education and Practice, Vol. 12 Iss 2 pp. $111-120$.

Pawel, D. Mankiewicz; Johan Truter (2014). "Creating and establishing a recovery-oriented clinical psychology provision across an acute care mental health pathway", Ethical obligation and clinical reality, Mental Health and Social Inclusion. Mental Health and Social Inclusion, Vol. 18, pp. 98 -104.
Rogers P, Qualter P, Phelps G, Gardner K. (2006). Belief in the paranormal, coping and emotional intelligence. Pers Individ Dif.41 (6): 1089-1105.

Saks A. M. (2006), Antecedents and consequences of employee engagement. Journal of Managerial Psychology, Vol. 21, No. 7.

Schaufeli, W., \& Bakker, A. (2013). UWES Utrecht Work Engagement Scale. Preliminary Manual [Version 1, November 2003]. Utrecht University: Occupational Health Psychology Unit.

Streicher B, Jonas E, Maier G W, Frey D and Spießberger A (2012) Procedural Fairness and Creativity: Does Voice Maintain People's Creative Vein Over Time? Creativity Research Journal. 24 (4) 358-63.

Tabarsa, G. \& Korbkandi, M. (2017). An investigation on the relationship between the employees' work engagement and their performance. Annual Conference of New Paradigms of Management in the Field of Intelligence.

Vidergor H. (2013). Profiles of creativity: A case study of a creative personality, International Journal for Talent Development and Creativity, Vol. 1, No. 1, 125- 135, 2013.
FAYEGH-MORADIHA, Hadi, SHIRAZIAN, Zahra, SALIMI, Freidoon and FAYEGH-MORADIHA, Mehdi. The effect of employees' emotional intelligence and engagement on their mental health with a focus on mediating role of mental creativity. ECORFAN Journal-Mexico. 2020 